\title{
Plant neighbour identity and invasive pathogen infection affect associational resistance to an invasive gall wasp
}

\author{
Pilar Fernandez-Conradi • Nicolas Borowiec $\cdot$ Xavier Capdevielle • \\ Bastien Castagneyrol - Alberto Maltoni - Cécile Robin · Federico Selvi • \\ Inge Van Halder • Fabrice Vétillard · Hervé Jactel
}

Received: 10 July 2017 / Accepted: 27 November 2017

(C) Springer International Publishing AG, part of Springer Nature 2017

\begin{abstract}
Theory predicts that mixed forests are more resistant to native pests than pure forests (i.e. associational resistance) because of reduced host accessibility and increased top-down control by natural enemies. Yet, whether the same mechanisms also apply to invasive pests remains to be verified. We tested the hypothesis of associational resistance against the invasive Asian chestnut gall wasp (ACGW, Dryocosmus kuriphilus) by comparing ACGW infestation rates on chestnuts (Castanea sativa) in stands varying in species composition (chestnut alone or associated with oaks, pines or ashes). We investigated the effects of reduced chestnut density and frequency in mixed stands, as well as the effect of biotic
\end{abstract}

Excepting for the first and last authors, the order of authors is alphabetical.

Electronic supplementary material The online version of this article (https://doi.org/10.1007/s10530-017-1637-4) contains supplementary material, which is available to authorized users.

P. Fernandez-Conradi $(\bowtie) \cdot X$. Capdevielle .

B. Castagneyrol · C. Robin · I. Van Halder .

F. Vétillard · H. Jactel

Biogeco, INRA, Univ. Bordeaux, 33610 Cestas, France

e-mail: pilar.fernandezconradi@gmail.com

\section{N. Borowiec}

INRA, Equipe Recherche et Développement en Lutte Biologique, UMR 1355, INRA, CNRS, Université Nice Côte d'Azur «Institut Sophia Agrobiotech »,

Sophia Antipolis, France interactions between ACGW, its parasitoids and the chestnut blight disease (caused by Cryphonectria parasitica). ACGW infestation rates were significantly lower in chestnut-oak and chestnut-ash mixtures than in pure chestnut stands and chestnut-pine mixtures. Infestation rate decreased with decreasing chestnut relative proportion. The composition of native parasitoid communities emerged from galls significantly differed between pure and mixed chestnut stands, but not the species richness or abundance of parasitoids. The abundance of the introduced parasitoid Torymus sinensis was not correlated with ACGW infestation rates and was independent of stand composition. Blight symptoms modified ACGW infestation rates with taller trees being preferred when they were asymptomatic but avoided when they presented blight disease damage. Our results suggest that conservation biological control based on tree species mixtures could contribute to reducing the damage of invasive forest pests.

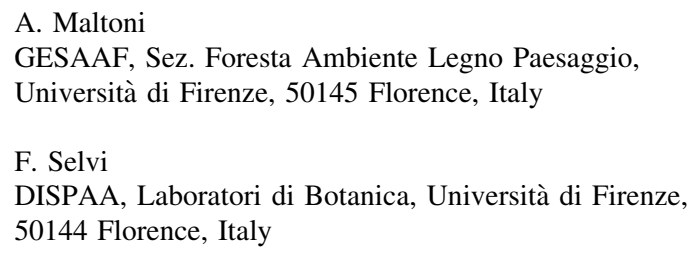


Keywords Biodiversity - Associational resistance · Invasive pest · Dryocosmus kuriphilus . Cryphonectria parasitica $\cdot$ Natural enemies

\section{Introduction}

Tree diversity provides support to multiple functions and services in forest ecosystems (Balvanera et al. 2006; Gamfeldt et al. 2013). Yet, biodiversity is increasingly threatened by invasive species, which have already caused alarming decline and local extinctions of native species (Clavero and Garciaberthou 2005; Galil 2007). A common view in invasion ecology is that communities with higher species richness are more resistant to the establishment and spread of invasive species (the diversityinvasibility relationship, Elton 1958). This idea received support (Case 1990; Erneberg 1999; Kennedy et al. 2002) mainly from plant ecologists (Levine et al. 2004), while much less is known about ecosystem resistance to invasive pest insects (Wilsey and Polley 2002). A few recent studies suggest that tree diversity in native communities may reduce the establishment and spread of invasive pests (Rigot et al. 2014; Guyot et al. 2015), but identifying the underlying mechanisms remains a major challenge (Nunez-Mir et al. 2017).

Associational resistance $(A R)$ is a likely mechanism explaining the greater resistance of species-rich plant communities to invasion by herbivorous insects. $A R$ describes the lower risk of a given plant being infested when surrounded by heterospecific neighbours (Jactel and Brockerhoff 2007; Barbosa et al. 2009). Although the opposite pattern-associational susceptibility $(A S)$ - can also be observed (White and Whitham 2000; Schuldt et al. 2015), AR seems a more common phenomenon in forest ecosystems (Jactel and Brockerhoff 2007; Castagneyrol et al. 2014a; but see Kambach et al. 2016). AR has been described mainly for native pest species but it can be hypothesized that similar mechanisms are involved for invasive pests (Jactel et al. 2006; Guyot et al. 2015).

$A R$ primarily occurs when the presence of heterospecific neighbours reduces the probability of a plant being colonized by herbivores, because these neighbours can reduce host plant concentration (i.e. species-specific density), frequency (i.e. relative proportion) and apparency (i.e. relative size). These mechanisms, however, are more likely to explain AR to herbivore specialists, with heterospecific neighbours being unsuitable hosts (Castagneyrol et al. 2014a, b). The "resource concentration hypothesis" (Tahvanainen and Root 1972; Hambäck et al. 2014) posits that herbivores are more able to locate and remain on hosts that are growing in high density or in nearly pure stands than in more diverse stands where their host plants are more diluted. How easily a host plant is found by herbivores, i.e. its apparency (Strauss et al. 2015), has been described as a key mechanism driving AR (Castagneyrol et al. 2013). Both visual (Dulaurent et al. 2012; Damien et al. 2016) and chemical (Zhang and Schlyter 2004; Jactel et al. 2011) cues used by insect herbivores to locate and colonize a host tree can be disrupted by the presence of heterospecific neighbours.

Host apparency may further be altered by biotic and abiotic factors interacting with plant diversity. For instance, fungal infections may modify plant quality (e.g., Hatcher et al. 1994; Cardoza et al. 2003), defensive traits (e.g., Cardoza et al. 2003), or even the emission of plant volatile compounds (e.g., Cardoza et al. 2002), that can be used by herbivores' natural enemies (e.g., Tack et al. 2012), resulting in the potential reduction of herbivorous insect performance and preference for a determined host plant (Tack and Dicke 2013). Infection of a host tree by fungal pathogens is thus an important but often neglected factor that can drive associational resistance. For instance, Schuldt et al. (2017) reported a positive relationship between damage of foliar herbivores and pathogens, which resulted in additive negative effects on tree growth. However tree species richness lead to $A S$ to insects but $A R$ to pathogens, with an overall reduced impact of both damaging agents combined on tree growth.

Associational effects may also result from topdown biotic interactions involving herbivores' enemies. The "enemies hypothesis" (Elton 1958; Root 1973) posits that plant communities with higher species richness provide more resources and habitats and thus can shelter more diverse predator or parasitoid communities (Wilby and Thomas 2002; Schuldt et al. 2011; Castagneyrol and Jactel 2012), which could in turn provide a better control of herbivore populations (Riihimäki et al. 2005; Leles et al. 2017). A spill-over of natural enemies from 
associated to target trees is expected if associated and target trees share common or alternative prey or hosts (Cappuccino et al. 1998). However, a greater abundance or diversity of herbivores' enemies does not necessarily result in higher predation rates as there is a wide range of enemy-enemy interactions that can be positive, negative or neutral (reviewed by Letourneau et al. 2009). Moreover, one of the proposed reasons for the success of alien herbivores (Shea and Chesson 2002) relates to the "enemy release hypothesis" (Keane and Crawley 2002) which states that their co-evolved natural enemies are virtually absent in newly colonized areas (Meijer et al. 2016). By contrast, the "exotic prey naïveté hypothesis" (Sih et al. 2010) posits that exotic, naïve species may suffer from higher predation pressures than native prey species because of its naïveté towards native enemies (Li et al. 2011). However, a few studies have taken into account pressure by native natural enemies on exotic species in invaded areas (but see Cox and Lima 2006; Li et al. 2011; Cabrera-Guzmán et al. 2012; Wilcox and Fletcher 2016).

Since 2002, European chestnut (Castanea sativa, Mill.) forests and orchards have been severely affected by the Asian chestnut gall wasp (ACGW), Dryocosmus kuriphilus Yasumatsu (Hymenoptera: Cynipidae). ACGW is considered the most important pest of Castanea species worldwide. It can cause chestnut productivity losses up to $80 \%$ (Battisti et al. 2014). Severe and repeated infestations on young trees can even lead to tree death (Moriya et al. 2003). Chestnut tree mortality may also occur when ACGW infestations are combined with strong chestnut blight infections (Cryphonectria parasitica, Murrill). ACGW is a micro-Hymenoptera (2-3 mm) native to China, which was introduced to Italy in early the 2000's from where it colonized almost all the European chestnut geographical range (Aebi et al. 2007; Quacchia et al. 2008). All members of the Cynipidae family are obligatory parasites of plants, either by inducing gall formation or by developing as inquilines within galls induced by other gall wasps (Stone et al. 2002).

Guyot et al. (2015) showed that crown defoliation caused by ACGW was significantly reduced in mixed chestnut stands compared to pure stands. However, little is known about underlying mechanisms of this $A R$ and particularly the role of other interacting organisms. For example, the chestnut blight, is now widely spread in all chestnut forests in Europe
(Rigling and Prospero 2017). This invasive fungus causes extensive necrosis in the cortical tissue (cankers) which can girdle trunks and branches and result in the death of the distal part. Recently, Meyer et al. (2015) showed that attacks by ACGW could increase the incidence of chestnut blight, because the latter can colonize abandoned galls and then establish in shoots usually not affected by the fungus. A reciprocal effect of chestnut blight on ACGW searching behavior may also occur but has not been documented yet. Interactions between two invaders in a new area may result in an 'invasional meltdown' process, i.e. invader-invader mutualism (Simberloff and Von Holle 1999). In particular a non-native pathogen (e.g., chestnut blight) may facilitate the establishment of a subsequent invader (e.g., ACGW), leading to exacerbated impact on native ecosystems (Simberloff and Von Holle 1999; Simberloff 2006). However the associational effects on co-occurring invasive pests remain largely unknown.

Here, we further investigate the pattern of reduced chestnut crown defoliation by ACGW in mixed stands found by Guyot et al. (2015) by examining whether ACGW infestation rates are altered by the identity of co-occurring tree species, tree apparency, or by biotic interactions among ACGW, its parasitoids, and chestnut blight disease. In particular, we predicted that: (1) heterospecific neighbours trigger $A R$ to ACGW; (2) $A R$ results from the dilution, i.e. reduced density and relative abundance, of chestnuts in mixed stands, (3) $A R$ is stronger in the presence of tree species also infected by Cynipidae galls that are likely to share parasitoids with ACGW, in particular Quercus species, and (4) infection by chestnut blight may modify ACGW infestation through changes in chestnut apparency. To test these hypotheses, we assessed ACGW infestation in chestnut trees naturally growing in pure versus two-species mixtures of different compositions. In the mixed stands, chestnut trees were associated with one of the three following native tree species: the turkey oak (Quercus cerris L., Fagaceae), a broadleaved species colonized by a high diversity of oak cynipid gall wasps, with associated parasitoids that have been already observed in ACGW galls (Aebi et al. 2007) and for which ACGW could present a "naïve prey"; the flowering ash (Fraxinus ornus L., Oleaceae), another broadleaved tree which is not known to be attacked by cynipid gall wasps, and the maritime pine (Pinus pinaster Aiton, Pinaceae), a 
conifer for which no cynipid gall maker is known and which is phylogenetically much more distant from chestnut than ash is. In each forest plot, we measured the density and relative abundance of chestnut trees. On each sampled chestnut tree we estimated ACGW infestation, chestnut blight severity, tree height and collected galls of ACGW to characterize parasitoids community.

\section{Materials and methods}

Study species

The current distribution of European chestnut ranges from Southern Europe (Iberian Peninsula, Italy, Balkans, Mediterranean islands) and North Africa (Morocco), to North-Western Europe (England, Belgium, Netherlands) and eastward to Western Asia (North East Turkey, Armenia, Georgia, Azerbaijan, Syria) (Conedera et al. 2016).

ACGW is a thelytokous and univoltine species (i.e. its populations are composed only by females which reproduce asexually once a year). At the time of chestnut bud-burst (around mid-April), ACGW larvae induce the formation of galls on different vegetative organs (Maltoni et al. 2012) within which they feed, develop and pupate. Between mid-June and midAugust adults hatch from the galls and lay eggs in new developing chestnut buds. Adult longevity can be up to 10 days. Following eggs hatching in summer, first instar larvae overwinter within dormant buds until the following spring (Bernardo et al. 2013).

ACGW populations are mainly regulated by hymenopteran parasitoids (Cooper and Rieske 2007). In Europe, ACGW galls are parasitized by native parasitoids of oak gall wasps (Panzavolta et al. 2013; Palmeri et al. 2014; Francati et al. 2015), and by a parasitoid wasp from its natural range, Torymus sinensis (Hymenoptera, Torymidae), which has been introduced in Europe as a biocontrol agent (see also Aebi et al. 2007; Borowiec et al. 2014; Matošević et al. 2014). Native to China, this parasitoid is univoltine (with about $3 \%$ of its population having a 12 months diapause period, Quacchia et al. 2014a, b; Ferracini et al. 2015), with adults emerging in early spring and females laying eggs in newly-formed ACGW galls. The ectoparasitoid larva feeds on the host larva and adults emerge in the following spring (Quacchia et al. 2014a).

Cryphonectria parasitica is an invasive plant pathogen native to Eastern Asia (Rigling and Prospero 2017). Its native range partly overlaps with that of ACGW in China (Zhang et al. 2009). This necrotrophic pathogenic fungus infects in the cortical tissues, causing extensive necrosis and cankers which can girdle trunks and branches. This results in the blight and then the death of the distal part (Rigling and Prospero 2017). Blight was first reported in American chestnut (Castanea dentata) in the United States in 1904 and in European chestnuts in Italy in 1938 (Rigling and Prospero 2017). It is a necrotrophic pathogen, which colonizes bark and cambium of chestnut trees through wounds, thereby destroying the function of these tissues in susceptible chestnut species such as Castanea sativa (Rigling and Prospero 2017).

\section{Study area}

The study was performed in natural forest stands in Southern Tuscany (Italy). These forests are mainly composed of chestnut (Castanea sativa), European hornbeam (Ostrya carpinifolia), oaks (Quercus ilex, $Q$. petraea, $Q$. suber, $Q$. pubescens and $Q$. cerris), ash (Fraxinus ornus) and pines (Pinus pinaster). In these stands, the chestnut was part of the original mixed broadleaved forests (native), then transformed into mostly pure stands for the production of wood and fruits. ACGW was officially reported in the study area for the first time in 2009 and T. sinensis was first released in 2010 (Maltoni, personal communication).

In February 2015, we selected 32 forest plots $(30 \times 30 \mathrm{~m})$ representing 10 chestnut monocultures and 22 two-species mixtures (Fig. S1). Mixtures associated chestnut with $Q$. cerris $(\mathrm{n}=10), F$. ornus $(\mathrm{n}=6)$ or $P$. pinaster $(\mathrm{n}=6)$. Mean plot elevation was $438 \mathrm{~m}$ above sea level. All plots were in similar conditions of soil and type of parent rock, e.g., siliceous crystalline quartzites and anagenites of "Verrucano" formation that are widespread in the study area (Lazzarotto 1993; Carmignani and Lazzarotto 2004). Soils deriving from this formation belong to the broad category of Cambisols (V.V.A.A. 2008), and are generally nutrient-poor and subject to acidification and moderate summer drought. Comparable site conditions among plots was also recently 
verified for the purpose of the FundivEurope project which involved the study of 36 forest plots close to those used in the present study (Baeten et al. 2013). Plots are located in the same vicinity as the study by Guyot et al. (2015), although only one plot from their study was used here.

In each plot, we sampled three focal chestnut trees, with either conspecific neighbours only (in monocultures) or both conspecific and heterospecific (in mixtures) neighbours in their immediate vicinity (i.e. tree canopies overlap; total: $\mathrm{n}=96$ sampled chestnut trees). Spatial coordinates of each focal chestnut tree and corners of plots were recorded using a Trimble ${ }^{\circledR}$ Geo 7X. We measured the diameter at breast height of all trees present in the plots. We also measured the total height of each focal chestnut tree, which was comparable for each type of plot composition (Table 1; see Table S1 for more details).

\section{Assessment of blight symptoms}

Severity of chestnut blight was assessed by recording cankers on stems and main branches. Cryphonectria parasitica was isolated in all accessible cankers, confirming they were caused by this pathogenic fungus.

\section{Assessment of ACGW infestation}

In May 2015, we collected 15 branches per focal chestnut tree, randomly selected around the tree crown. For each collected branch, we recorded the number of galls per shoot in all new shoots. New shoots, i.e. those produced during spring 2015, corresponded to buds of the previous year, i.e. those susceptible to be attacked by ACGW the previous year. As such, gall infestation observed in 2015 corresponded to eggs laid in summer 2014. Infestation rate by ACGW was estimated as the number of infested shoots (i.e. presenting at least one gall).

\section{Parasitoid collection}

In winter 2015, we randomly collected 25 galls on eight branches per focal chestnut tree (total: $n=200$ galls per tree). In laboratory "winter galls" were stored in cardboard boxes (one box per tree) with extractable tubes exposed to light. Boxes were maintained in a climatic chamber at $25^{\circ} \mathrm{C}$, with $12 \mathrm{~h}$ daylight. Boxes were surveyed every 2-3 days and emerged parasitoids were collected, stored at $-20{ }^{\circ} \mathrm{C}$, and then transferred in $96 \%$ ethanol for further identification. In May 2015, we also collected 100 green galls per tree. These "spring galls" were surveyed for parasitoid emergence as described above for the winter galls.

Parasitoids emerging from winter and spring galls were identified at least to the genus level under a stereomicroscope (Leica M205C). Winter galls were expected to host overwintering parasitoids, and in particular T. sinensis. Spring galls were sampled to collect native parasitoids of oak gall wasps that were expected to parasitize ACGW larvae. They belong to six main families of chalcid wasps (Eulophidae, Eupelmidae, Eurytomidae, Ormyridae, Pteromalidae, Torymidae), and have been identified on oak cynipids (Askew et al. 2013) or on ACGW (Aebi et al. 2006, 2007; Panzavolta et al. 2013; Al Khatib et al.

Table 1 Mean $( \pm$ SD) plot characteristics for each type of composition

\begin{tabular}{|c|c|c|c|c|c|}
\hline $\begin{array}{l}\text { Plot } \\
\text { composition }\end{array}$ & $\begin{array}{l}\text { Chestnut basal area } \\
\left(\mathrm{cm}^{2} / \mathrm{m}^{2} \text { plot }\right)\end{array}$ & $\begin{array}{l}\text { Total trees basal area } \\
\left(\mathrm{cm}^{2} / \mathrm{m}^{2} \text { plot }\right)\end{array}$ & $\begin{array}{l}\text { Chestnut relative } \\
\text { proportion (in basal area) }\end{array}$ & $\begin{array}{l}\text { Focal chestnut } \\
\text { height }(\mathrm{m})\end{array}$ & $\begin{array}{l}\text { C. parasitica } \\
\text { symptomatic trees }\end{array}$ \\
\hline $\begin{array}{l}\mathrm{CS} \\
\quad(\mathrm{n}=10)\end{array}$ & $44.59 \pm 44.58$ & $45.66 \pm 45.18$ & $0.97 \pm 0.05$ & $11.92 \pm 1.83$ & $60 \%(\mathrm{n}=30)$ \\
\hline $\begin{array}{l}\text { CS-FO } \\
\quad(n=6)\end{array}$ & $13.50 \pm 11.52$ & $24.29 \pm 28.32$ & $0.62 \pm 0.23$ & $10.36 \pm 3.85$ & $56 \%(\mathrm{n}=18)$ \\
\hline $\begin{array}{l}\text { CS-PP } \\
\quad(n=6)\end{array}$ & $43.80 \pm 32.86$ & $70.92 \pm 43.17$ & $0.60 \pm 0.20$ & $10.89 \pm 4.33$ & $72 \%(\mathrm{n}=18)$ \\
\hline $\begin{array}{l}\text { CS-QC } \\
\quad(\mathrm{n}=10)\end{array}$ & $23.35 \pm 30.13$ & $46.24 \pm 29.31$ & $0.38 \pm 0.26$ & $10.13 \pm 3.03$ & $50 \%(\mathrm{n}=30)$ \\
\hline
\end{tabular}

$C S$, Castanea sativa (monocultures); CS-PP, C. sativa + P. pinaster; CS-FO, C. sativa + Fraxinus ornus; CS-QC, C. sativa + Quercus cerris 
2014, 2015, 2016; Palmeri et al. 2014). It is important to note that for some wasps, molecular characterization (Cytochrome Oxydase I) revealed the presence of probable cryptic species (Borowiec, unpubl. data), especially for Ormyrus nitidulus and O. pomaceus (Kaartinen et al. 2010; Lotfalizadeh et al. 2012; Goméz et al. 2017). For this reason, specimens of Ormyrus were not identified at species level.

\section{Statistical analysis}

General approach. Data analysis was performed with generalized linear mixed models (GLMMs) following the procedure recommended by Zuur et al. (2009). Plot identity was included as a random factor (1/Plot.ID in $R$ syntax) to account for the correlated data structure arising from the three replicate focal trees sampled per plot (Schielzeth and Nakagawa 2013). Significance of parameters was assessed using $\chi^{2}$ tests by comparing models with and without the term to be tested. We applied model simplification by starting with the highest order interaction and sequentially removing non-significant predictors. After the most parsimonious model had been reached, parameter estimates corresponding to fixed effects were estimated by restricted maximum likelihood (REML). Contrast analyses were used to compare levels of significant factors. To estimate model fit, $R^{2}$ were calculated following Nakagawa and Schielzeth (2013). For each model, we calculated the marginal $R^{2}\left(R_{m}^{2}\right.$, corresponding to the proportion of variance explained by fixed effects) and the conditional $R^{2}\left(R_{c}^{2}\right.$, corresponding to variance explained by fixed plus random effects). All analyses were conducted in 3.2.3 version of $\mathrm{R}$ ( $\mathrm{R}$ Core Team 2015), using the glmer function from the lme4 package (Bates et al. 2015).

First, we tested the effect of chestnut forest composition as a categorical fixed-effect factor with four levels (pure chestnut stand, CS; mixture of chestnut and ash, CS-FO; mixture chestnut and pine, CS-PP; mixture chestnut and oak, CS-QC) on ACGW infestation. We analyzed ACGW infestation rate as the proportion of shoots with at least one gall by using a bivariate response variable consisting in number of shoots with at least one gall versus number of shoots with no gall. We used a GLMM with binomial error distribution and logit function such that fitted values were bounded between 0 and 1 .
Second, to assess mechanisms that might explain the effect of chestnut forest composition, we ran another model with the general structure described above but with different predictors. This model included three types of predictors referring to (1) tree species composition, (2) bottom-up and (3) top-down associational resistance effects. The composition effect (1) was described by two continuous variables: chestnut density (i.e. chestnut basal area) and chestnut frequency, as its relative proportion to other species in the plot (measured as the ratio between chestnut basal area and basal area of all tree species present in the plot). Bottom-up processes (2) were accounted for, at the tree level, by including as fixed effects the presence/absence of blight symptoms, chestnut height and their interaction. Top-down processes (3) were accounted for, at the tree level, by including the number of parasitoids that emerged from winter and spring galls as separate fixed effects. This approach resulted in one model that was simplified as explained above. Despite the weak correlation between chestnut density and proportion (Pearson's $r=0.22$ ), both were introduced in the same model (Dormann et al. 2013). A marginal test of predictor significance was used by testing whether some variance remained explained by each predictor once other sources of variation in the response variable were accounted for. Torymus sinensis was the most common parasitoid emerging from winter galls (94\% of individuals). So, in order to avoid correlation between $T$. sinensis and total winter parasitoid abundance, the effect of $T$. sinensis as biocontrol agent on ACGW was specifically tested in a separated model with ACGW infestation rates as a binomial response variable, as explained above.

Third, we analyzed the effect of plot composition on parasitoid abundance (number of parasitoids from winter galls per tree in one model, number of $T$. sinensis specifically in a second one, and number of parasitoids from spring galls in a third one) with a Poisson error distribution.

Finally, a non-metric multidimensional scaling (NMDS) was performed on parasitoid data in order to test whether and how the composition of spring gall parasitoid communities varied according to the tree species composition of plots. This was not investigated with the communities of parasitoids emerging from winter galls because they were dominated by $T$. sinensis. The significance of tree composition in the 
plot on parasitoid community composition was tested with a PERMANOVA (Anderson 2005) using the 'adonis' function from package 'vegan' (Oksanen et al. 2017). We performed 1000 permutations using Bray-Curtis' dissimilarity measure. Parasitoid diversity was estimated by calculating Shannon's index with the 'diversity' function. Significance of composition effect on Shannon indices was tested by using GLMMs as described above, using Gaussian error distribution, after linearization of the index to obtain the 'effective species number' (Jost 2006).

\section{Results}

All the 96 sampled chestnut trees were infested by ACGW. The proportion of shoots infested by ACGW (i.e. infestation rate) was on average $78 \%$ and varied between 30 and $100 \%$ per tree. Infestation rates significantly differed among plots of different tree species composition $\left(\chi^{2}=15.66, d f=3, P=0.001\right.$, $\left.R_{m}^{2}=0.15, R_{c}^{2}=0.34\right)$ being significantly lower in ash- and oak-chestnut mixtures as compared to chestnut monocultures (Fig. 1a). In pine-chestnut mixtures, infection rates were intermediate between chestnut monocultures and chestnut-ash mixtures (Fig. 1a).

The infestation rate by ACGW significantly increased with the relative proportion of chestnut trees in plots (Table 2, Fig. 1b), but was independent of chestnut density (Table 2).

The infestation rate by ACGW varied with chestnut blight symptoms in interaction with tree height (Table 2). In asymptomatic trees, ACGW infestation rate increased with chestnut tree height (Fig. 2; Table 2) while ACGW infestation rates decreased with chestnut height in symptomatic trees (Fig. 2; Table 2).

A total of 1619 parasitoids were collected from winter galls, with a mean number of 16 (varying from 0 to 300) parasitoids emerging from 200 winter galls per tree. Nine trees did not provide any parasitoid. In winter galls, T. sinensis represented $94 \%$ of total parasitoid abundance.

From spring galls, a total of 814 parasitoids emerged, with a mean number of 8 parasitoids per 100 galls (varying from 0 to 35 ). Ten trees had no parasitoids in their spring galls. The most abundant species were Torymus auratus and Torymus flavipes that represented respectively 34 and $26 \%$ of the total number of parasitoids collected (see also Table S2 for additional information about parasitoids species found). The effect of tree species composition of plots was significant but explained only $16 \%$ of variance in the composition of parasitoid communities emerging from spring galls (PERMANOVA pseudo- $F=1.76$, $P=0.021$, Fig. 3).

The infestation rate by ACGW was independent of total parasitoid abundance in winter or spring galls (Table 2). ACGW infestation rate was also independent of $T$. sinensis abundance $\left(\chi^{2}=1.78, d f=1\right.$, $P=0.18)$. Total parasitoid abundance was independent of plot composition for winter $\left(\chi^{2}=4.22\right.$, $\left.d f=3, P=0.238, R_{m}^{2}=0.08, R_{c}^{2}=0.58\right)$ and spring galls $\left(\chi^{2}=2.77, d f=3, \quad P=0.428, R_{m}^{2}=0.03\right.$, $\left.R_{c}^{2}=0.27\right)$. The species richness and diversity of parasitoids were also independent of plot composition $\left(\chi^{2}=0.877, d f=3, \quad P=0.831\right.$ and $\chi^{2}=1.08$, $d f=3, P=0.781$ respectively; Table 3 ). The abundance of $T$. sinensis found in winter galls was also independent of plot composition $\left(\chi^{2}=6.31, d f=3\right.$, $P=0.098)$.

\section{Discussion}

ACGW infestation rates depend on tree neighbour identity

We not only confirmed previous observations reporting $A R$ to the ACGW (Guyot et al. 2015), we provide evidence that this effect is dependent on the identity of the tree species associated with chestnut trees. $A R$ occurred only in the two-species mixtures where chestnut trees were associated with another broadleaved species, with infestation rates on average $13.9 \%$ lower than in monocultures (Fig. 1a). Such reduction in ACGW infestation may be important for chestnut survival, even if mean infestation rates in mixtures with oak and ashes were still high (71.5 and $74.1 \%$ respectively; Fig. 1a). Infestation rates in chestnut-pine mixtures, however, were comparable to that in monocultures (Fig. 1a). This last finding conflicts with the prediction that $A R$ should be stronger in mixtures of more distantly related species such as mixtures of conifers and broadleaved species 
(A)

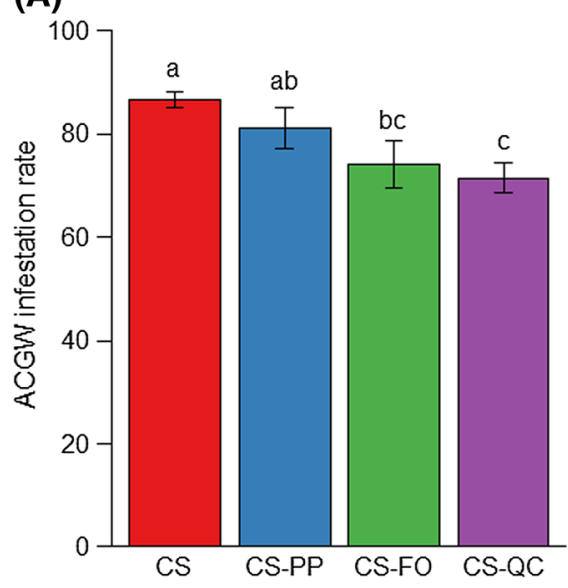

Fig. 1 Mean ACGW infestation rate per chestnut tree as a function of, a tree species composition and $\mathbf{b}$ chestnut frequency (i.e. relative proportion of chestnut basal area to basal area of all tree species in the plot). In $\mathbf{a}$, different letters indicate significant differences between treatments (at $P<0.05$ ). In $\mathbf{b}$ the line

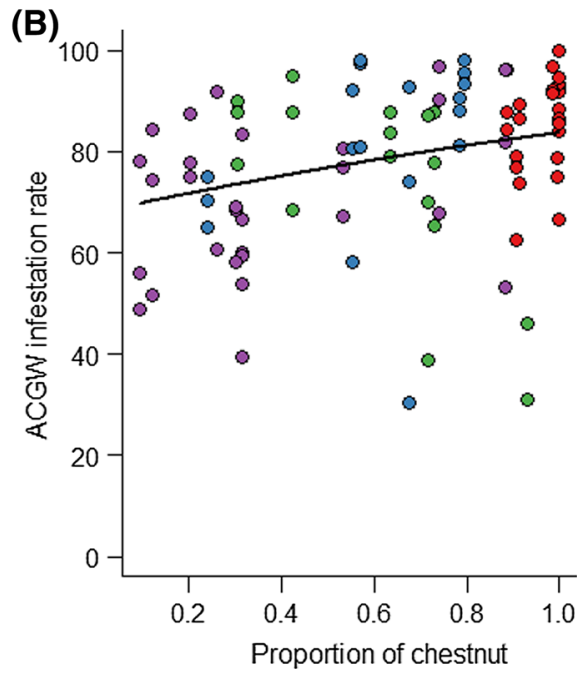

represents model predictions after back-transformation of the logit link applied to binomial GLMMs. CS Castanea sativa (monocultures); $C S-P P C$. sativa + Pinus pinaster; $C S-F O C$. sativa + Fraxinus ornus; $C S-Q C$ C. sativa + Quercus cerris. Colors in B correspond to tree species compositions in a

Table 2 Summary of generalized linear mixed effect model evaluating the effects of stand structure and composition, natural enemies pressure and two-way interactions, on ACGW infestation rate

\begin{tabular}{lccccc}
\hline Fixed effects & $\chi^{2}$ & $d f$ & $P$ & Estimate & SE \\
\hline Intercept & & & & 1.31 & 0.14 \\
Chestnut density & 2.24 & 1 & 0.137 & 0.20 & 0.13 \\
Chestnut relative proportion & 4.05 & 1 & $\mathbf{0 . 0 4 6}$ & 0.27 & 0.13 \\
Chestnut blight symptoms (symptomatic) & 5.82 & 1 & $\mathbf{0 . 0 1 5}$ & -0.21 & $\mathbf{0 . 1 3}$ \\
Height & 0.03 & 1 & 0.918 & -0.20 & $\mathbf{0 . 0 9}$ \\
Parasitoids abundance in spring galls & 0.09 & 1 & 0.838 & 0.01 & $\mathbf{0 . 0 6}$ \\
Parasitoids abundance in winter galls & 0.14 & 1 & 0.651 & 0.03 & $\mathbf{0 . 0 7}$ \\
Chestnut density $\times$ relative proportion & 0.65 & 1 & 0.419 & -0.16 & $\mathbf{0 . 2 0}$ \\
Chestnut blight symptoms $\times$ height & 16.49 & 1 & $<\mathbf{0 . 0 0 1}$ & -0.47 & $\mathbf{0 . 1 2}$ \\
\hline
\end{tabular}

Model parameter estimates and standard errors for the intercept correspond to the reference level for chestnut blight: asymptomatic trees. Marginal $\mathrm{R}_{\mathrm{m}}^{2}$ represents the variance explained by fixed factors, while conditional $\mathrm{R}_{\mathrm{c}}^{2}$ is interpreted as variance explained by both fixed and random factors. For the final model (retained after model selection), they equaled 0.14 and 0.36 , respectively

Explanatory variables in bold characters had a significant effect for $\chi^{2}$ values (at $P<0.05$ )

(Castagneyrol et al. 2014a). However, ACGW is a highly specialized pest with only one host species in the study area (Bernardo et al. 2013). In this context, Castagneyrol et al. (2014a) showed that host frequency should be the main driver of $A R$.
Host dilution in mixed stands resulted in lower ACGW infestation rates

Chestnut density per se had no significant effect on ACGW infestation rates (Table 2), which goes against the resource concentration hypothesis (Root 1973; 
Fig. 2 AGCW infestation rate per chestnut tree as a function of chestnut height, in symptomatic versus asymptomatic chestnut blight trees. Lines represent model predictions after back-transformation of the logit link applied to binomial GLMMs. Different point colors represent different plot composition: chestnut monocultures (red) and pine (blue), ash (green) and oak (purple) two species chestnut mixtures

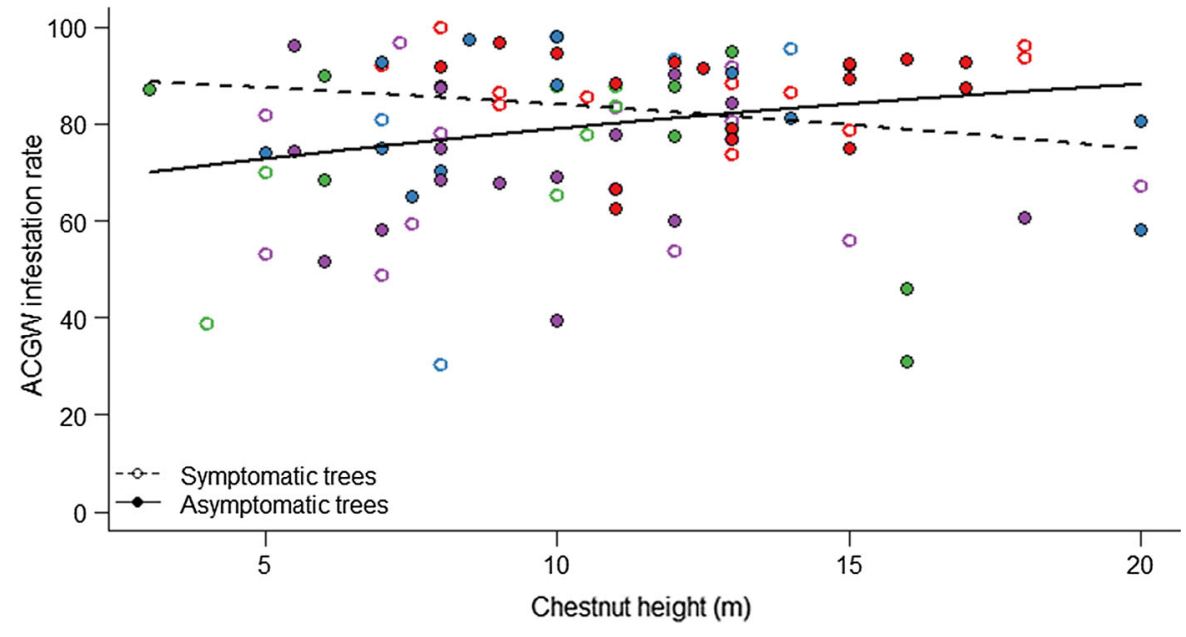

Fig. 3 NMDS of parasitoid communities from spring ACGW galls. In a species identity distribution and in $\mathbf{b}$ sites relative distribution. CS, Castanea sativa (monocultures); $C S-P P, C$.

Hambäck et al. 2014). However, we demonstrated that chestnut infestation by ACGW was reduced when chestnut was less frequent, i.e. more diluted among non-host neighbours (Fig. 1b; Table 2). An increasing dilution between non-host trees is an important driver of $A R$ (Hambäck and Beckerman 2003; Jactel et al. 2006; Damien et al. 2016). This dilution effect on ACGW infestation rates could be explained by sativa + Pinus pinaster CS-FO, C. sativa + Fraxinus ornus; $C S-Q C, C$. sativa + Quercus cerris. The stress value associated with this representation was 0.167

heterospecific neighbours acting as physical (Castagneyrol et al. 2014b; Damien et al. 2016) or chemical barriers (Tahvanainen and Root 1972; Randlkofer et al. 2010; Jactel et al. 2011) to chestnut localisation by ACGW (see also Germinara et al. 2011). 
Table 3 Mean parasitoid abundance ( \pm SE), species richness and Shannon diversity per plot for each plot composition: chestnuts monocultures (CS) and ash (CS-FO), pine (CS-PP) and oak (CS-QC) mixtures

\begin{tabular}{lrccc}
\hline & CS $(\mathrm{n}=10)$ & CS-PP $(\mathrm{n}=6)$ & CS-FO $(\mathrm{n}=6)$ & CS-QC $(\mathrm{n}=10)$ \\
\hline Abundance & $27.10 \pm 1.30$ & $15.00 \pm 4.99$ & $23.50 \pm 4.65$ & $27.10 \pm 0.68$ \\
Species richness & $5.70 \pm 3.16$ & $5.33 \pm 0.99$ & $5.00 \pm 0.97$ & $6.00 \pm 0.68$ \\
Shannon diversity & $1.23 \pm 0.04$ & $1.44 \pm 0.20$ & $1.16 \pm 0.18$ & $1.29 \pm 0.13$ \\
\hline
\end{tabular}

Blight symptoms in interaction with chestnut apparency modifies ACGW infestations

In our study, we show that ACGW infestation rates were higher in taller trees than on smaller ones for trees without blight symptoms (Fig. 2). This is consistent with previous observations by Maltoni et al. (2012), who found that vigorous chestnut trees are more attacked than dominated or weak chestnuts. These results suggest that taller, more apparent and more vigorous trees are preferred by female ACGW for laying eggs. However, because we counted galls and not oviposition events, we cannot exclude that differences in observed infestation rates were driven by differential mortality after oviposition. It remains possible that ACGW females did not choose among stands and trees, but larvae developed more successfully in more vigorous trees.

However, the host apparency effect was not observed on trees severely infected by chestnut blight. In these trees, ACGW infestation rates were higher in smaller trees than in taller ones (Fig. 2). The presence of $C$. parasitica in cankers of American chestnut $(C$. dentata) results in stomatal closure, possibly as a direct result of xylem dysfunction (McManus and Ewers 1990), thus, in trees with blight symptoms water transport might be more impaired than in asymptomatic trees. This might be more severe in large than in small trees. As a consequence, foliar tissues might be of lower quality as breeding substrate for ACGW in large and blight symptomatic trees. Fungal infection of a plant can also modify host visual and chemical cues used for the insect to locate its host (Cardoza et al. 2002, 2003; Rizvi et al. 2015), thus interfering with tree apparency. Knowing how chestnut blight modifies chestnut traits used by ACGW to locate and exploit host trees (e.g., Germinara et al. 2011) would provide useful information about their combined impact.
The co-occurrence of blight and ACGW on smaller chestnut trees could be a case of invasional meltdown, with a more severe, combined adverse effect on survival and growth of young chestnut trees, thus jeopardizing natural regeneration. However, our data does not allow us to properly test such invasional meltdown as we could not reported independent impact of each exotic aggressors (all trees were infected by ACGW and likely by $C$. parasitica).

Abundances of ACGW parasitoids were independent of forest composition

Invasion success of exotic pests are usually attributed to the absence of co-evolved natural enemies in the new colonized area ('enemy release hypothesis', e.g., Keane and Crawley 2002). At the time of its establishment in Italy, ACGW found an 'enemy free space', allowing the pest to rapidly build up its populations. However few years later a spill-over of native parasitoids was already observed from oak gall onto ACGW galls (Aebi et al. 2006, 2007; Panzavolta et al. 2013), suggesting that ACGW became a 'naïve prey' (Sih et al. 2010) for local, native enemies.

Due to this spill-over process, we expected a better top-down control of ACGW by natural enemies in chestnut-oak mixed stands ('enemies hypothesis', Elton 1958; Root 1973). However, we did not detect any correlation between parasitoid abundance and ACGW infestation rate (Table 2), and the parasitoid abundance was independent of stand composition. We found native parasitoids in all stands (Fig. 3), even though no cynipid gall wasps are known on Pinus or Fraxinus species (Csoka et al. 2005). The more likely explanation is the presence of oak species (Q. petraea, $Q$. pubescens) in the vicinity of our plots, which was not controlled in our study, and may have represented nearby sources of native cynipid parasitoids. 
Moreover, the parasitism rate by native species was on average of ca. 8 individuals per 100 galls, which was relatively low compared with the mean parasitism rate of oak cynipids as reported in the literature (e.g., Fernandes and Price 1992). This suggests that oak trees may have also acted as a sink for native parasitoids, i.e. oak galls being more suitable hosts. Some parasitoid species could have indeed avoided ACGW galls and concentrated on native hosts as infecting a new introduced host may incur a fitness cost for native parasitoids (Jones et al. 2015; Knoll et al. 2017).

We did not detect either an effect of $T$. sinensis abundance on ACGW infestation rate. However, the introduction of this exotic parasitoid, originating from the native area of ACGW in Asia, in Tuscany was relatively recent (2010), which is consistent with the low abundance of $T$. sinensis observed on ACGW galls (on average 15 parasitoids for 200 galls). Yet, it took 8 years following the first releases of $T$. sinensis to achieve an effective reduction of $75 \%$ of ACGW infestations in the Piedmont Region, Italy (Quacchia et al. 2014b). We may expect that the combined effects of native and exotic parasitoids will contribute to better reduce ACGW populations in the future. However, whether native parasitoids only (those produced by oak galls) would have been effective enough to control ACGW outbreaks in mixed forests remains an open question.

Last, it must be also acknowledged that parasitoids represent a fraction of ACGW' enemies and that variability in ACGW infestation rates could be explained by the effects of endophytic fungi (ex. Gnomoniopsis castanea, Vannini et al. 2017) or of competing generalist herbivores (Cooper and Rieske 2010; Tosi et al. 2015).

\section{Conclusion}

Our study provides new empirical data supporting the hypothesis that mixed forests are more resistant to biological invasions by exotic pests than tree monocultures. Our results suggest that the strength of associational resistance to invasive insects depends on both the quality (i.e. the identity of associated tree species) and the quantity of non-host trees in mixed stands. In addition, our observations suggest that complex biotic interactions might mediate these mechanisms. For example, plant infection by a pathogenic fungi may modify $A R$ to pests.

Classical biological control, i.e. the introduction of natural enemies native to the area of origin of the pest for its permanent establishment in a new area (Eilenberg et al. 2001), is the most common strategy used to regulate ACGW populations worldwide. However, although $T$. sinensis was present in winter galls from almost all trees that we sampled, the parasitism rates are still low and we thus observed a high level of ACGW damage, ranging from 30 to $100 \%$ infested shoots. Our findings suggest that forest management practices, based on tree species mixtures, would provide a complementary protection against ACGW, along the lines of the conservation biological control strategy (Barbosa 1998). As additional advantage of mixed-species forests represent a preventive method which might help to reduce the risk posed by other natural disturbances, including further biological invasions (Jactel et al. 2017).

Acknowledgements We thank Dr. John Parker and two anonymous reviewers for constructive comments on an earlier version of the manuscript. We thank Marcel Thaon and Benoit Cailleret (INRA, ISA) for assistance with parasitoid identification. Pilar Fernandez-Conradi was supported by a grant from INRA (Department of Forest, Grassland and Freshwater Ecology) and the French Ministry of Agriculture and Forestry.

\section{References}

Aebi A, Schönrogge K, Melika G et al (2006) Parasitoid recruitment to the globally invasive chestnut gall wasp Dryocosmus kuriphilus. In: Ozaki K, Yukawa J, Ohgushi T, Price PW (eds) Galling arthropods and their associates. Springer, Berlin, pp 103-121

Aebi A, Schönrogge K, Melika G et al (2007) Native and introduced parasitoids attacking the invasive chestnut gall wasp Dryocosmus kuriphilus. EPPO Bull 37:166-171

Al Khatib F, Fusu L, Cruaud A et al (2014) An integrative approach to species discrimination in the Eupelmus urozonus complex (Hymenoptera, Eupelmidae), with the description of 11 new species from the Western Palaearctic. Syst Entomol 39:806-862

Al Khatib F, Fusu L, Cruaud A et al (2015) Availability of eleven species names of Eupelmus (Hymenoptera, Eupelmidae) proposed in Al khatib et al. (2014). ZooKeys 505:137-145. https://doi.org/10.3897/zookeys.505.9021

Al Khatib F, Cruaud A, Fusu L et al (2016) Multilocus phylogeny and ecological differentiation of the "Eupelmus urozonus species group" (Hymenoptera, Eupelmidae) in the West-Palaearctic. BMC Evol Biol 16:13. https://doi. org/10.1186/s12862-015-0571-2 
Anderson MJ (2005) Permutational multivariate analysis of variance. Department of Statistics, University of Auckland, Auckland, vol 26, pp 32-46

Askew RR, Melika G, Pujade-Villar J et al (2013) Catalogue of parasitoids and inquilines in cynipid oak galls in the West Palaearctic. Zootaxa 3643:1. https://doi.org/10.11646/ zootaxa.3643.1.1

Baeten L, Verheyen K, Wirth C et al (2013) A novel comparative research platform designed to determine the functional significance of tree species diversity in European forests. Perspect Plant Ecol Evolut Syst 15:281-291. https://doi.org/10.1016/j.ppees

Balvanera P, Pfisterer AB, Buchmann N et al (2006) Quantifying the evidence for biodiversity effects on ecosystem functioning and services. Ecol Lett 9:1146-1156. https:// doi.org/10.1111/j.1461-0248.2006.00963.x

Barbosa P (1998) Conservation biological control. Academic AP Press, New York

Barbosa P, Hines J, Kaplan I et al (2009) Associational resistance and associational susceptibility: having right or wrong neighbors. Annu Rev Ecol Evol Syst 40:1-20. https://doi.org/10.1146/annurev.ecolsys.110308.120242

Bates D, Martin M, Bolker B, Walker S (2015) Fitting linear mixed-effects models using lme4. J Stat Softw 1:1-48

Battisti A, Benvegnù I, Colombari F, Haack RA (2014) Invasion by the chestnut gall wasp in Italy causes significant yield loss in Castanea sativa nut production: chestnut gall wasp and impact on nut yield. Agric For Entomol 16:75-79. https://doi.org/10.1111/afe.12036

Bernardo U, Iodice L, Sasso R et al (2013) Biology and monitoring of Dryocosmus kuriphilus on Castanea sativa in Southern Italy. Agric For Entomol 15:65-76. https://doi. org/10.1111/j.1461-9563.2012.00588.x

Borowiec N, Thaon M, Brancaccio L et al (2014) Classical biological control against the chestnut gall wasp'Dryocosmus kuriphilus'(Hymenoptera, Cynipidae) in France. Plant Prot Q 29:7

Cabrera-Guzmán E, Crossland MR, Shine R (2012) Predation on the eggs and larvae of invasive cane toads (Rhinella marina) by native aquatic invertebrates in tropical Australia. Biol Conserv 153:1-9. https://doi.org/10.1016/j. biocon.2012.04.012

Cappuccino N, Lavertu D, Bergeron Y, Régnière J (1998) Spruce budworm impact, abundance and parasitism rate in a patchy landscape. Oecologia 114:236-242. https://doi. org/10.1007/s004420050441

Cardoza YJ, Alborn HT, Tumlinson JH (2002) In vivo volatile emissions from peanut plants induced by simultaneous fungal infection and insect damage. $J$ Chem Ecol 28:161-174

Cardoza YJ, Lait CG, Schmelz EA et al (2003) Fungus-induced biochemical changes in peanut plants and their effect on development of beet armyworm, Spodoptera exigua Hübner (Lepidoptera: Noctuidae) larvae. Environ Entomol 32:220-228

Carmignani L, Lazzarotto A (2004). Geological map of Tuscany. Regione Toscana and University of Siena

Case T (1990) Invasion resistance arises in strongly interacting species-rich model competition communities. Proc Natl Acad Sci U S A 87:9610-9614. https://doi.org/10.1073/ pnas.87.24.9610
Castagneyrol B, Jactel H (2012) Unraveling plant-animal diversity relationships: a meta-regression analysis. Ecology 93:2115-2124

Castagneyrol B, Giffard B, Péré C, Jactel H (2013) Plant apparency, an overlooked driver of associational resistance to insect herbivory. J Ecol 101:418-429. https://doi.org/10. $1111 / 1365-2745.12055$

Castagneyrol B, Jactel H, Vacher C et al (2014a) Effects of plant phylogenetic diversity on herbivory depend on herbivore specialization. J Appl Ecol 51:134-141. https://doi.org/10. 1111/1365-2664.12175

Castagneyrol B, Regolini M, Jactel H (2014b) Tree species composition rather than diversity triggers associational resistance to the pine processionary moth. Basic Appl Ecol 15:516-523. https://doi.org/10.1016/j.baae.2014.06.008

Clavero M, Garciaberthou E (2005) Invasive species are a leading cause of animal extinctions. Trends Ecol Evol 20:110. https://doi.org/10.1016/j.tree.2005.01.003

Conedera M, Tinner W, Krebs P, et al (2016) Castanea sativa in Europe: distribution, habitat, usage and threats. In: SanMiguel-Ayanz J, de Rigo D, Caudillo G, Houston Durrant T, Maurl A (eds) European atlas of forest tree species

Cooper WR, Rieske LK (2007) Community associates of an exotic gallmaker, Dryocosmus kuriphilus (Hymenoptera: Cynipidae), in Eastern North America. Ann Entomol Soc Am 100:236-244. https://doi.org/10.1603/00138746(2007)100[236:CAOAEG]2.0.CO;2

Cooper WR, Rieske LK (2010) Gall structure affects ecological associations of Dryocosmus kuriphilus (Hymenoptera: Cynipidae). Environ Entomol 39:787-797. https://doi.org/ 10.1603/EN09382

Cox JG, Lima SL (2006) Naiveté and an aquatic-terrestrial dichotomy in the effects of introduced predators. Trends Ecol Evol 21:674-680. https://doi.org/10.1016/j.tree.2006. 07.011

Csoka G, Stone GN, Melika G (2005) Biology, ecology and evolution of gall-inducing Cynipidae. In: Raman A, Schaefer CW, Withers T (eds) Biology, ecology, and evolution of gall-inducing arthropods. Science Publisher Inc, Enfield, pp 573-642

Damien M, Jactel H, Meredieu C et al (2016) Pest damage in mixed forests: disentangling the effects of neighbor identity, host density and host apparency at different spatial scales. For Ecol Manag 378:103-110. https://doi.org/10. 1016/j.foreco.2016.07.025

Dormann CF, Elith J, Bacher S et al (2013) Collinearity: a review of methods to deal with it and a simulation study evaluating their performance. Ecography 36:27-46. https:// doi.org/10.1111/j.1600-0587.2012.07348.x

Dulaurent A-M, Porté AJ, van Halder I et al (2012) Hide and seek in forests: colonization by the pine processionary moth is impeded by the presence of nonhost trees. Agric For Entomol 14:19-27. https://doi.org/10.1111/j.14619563.2011.00549.x

Eilenberg J, Hajek A, Lomer C (2001) Suggestions for unifying the terminology in biological control. Biocontrol 46:387-400. https://doi.org/10.1023/A:1014193329979

Elton CS (1958) The ecology of invasions by animals and plants. https://www.abebooks.com/Ecology-Invasions-AnimalsPlants-Paperback-Charles/14774974829/bd. Accessed 20 Mar 2017 
Erneberg M (1999) Effects of herbivory and competition on an introduced plant in decline. Oecologia 118:203-209. https://doi.org/10.1007/s004420050719

Fernandes GW, Price PW (1992) The adaptive significance of insect gall distribution: survivorship of species in xeric and mesic habitats. Oecologia 90:14-20. https://doi.org/10. 1007/BF00317803

Ferracini C, Ferrari E, Saladini MA et al (2015) Non-target host risk assessment for the parasitoid Torymus sinensis. Biocontrol 60:583-594. https://doi.org/10.1007/s10526-0159676-1

Francati S, Alma A, Ferracini C et al (2015) Indigenous parasitoids associated with Dryocosmus kuriphilus in a chestnut production area of Emilia Romagna (Italy). Bull Insectol 68:127-134

Galil BS (2007) Loss or gain? Invasive aliens and biodiversity in the Mediterranean Sea. Mar Pollut Bull 55:314-322. https://doi.org/10.1016/j.marpolbul.2006.11.008

Gamfeldt L, Snäll T, Bagchi R et al (2013) Higher levels of multiple ecosystem services are found in forests with more tree species. Nat Commun 4:1340. https://doi.org/10.1038/ ncomms 2328

Germinara GS, De Cristofaro A, Rotundo G (2011) Chemical cues for host location by the chestnut gall wasp, Dryocosmus kuriphilus. J Chem Ecol 37:49-56. https://doi.org/ 10.1007/s10886-010-9893-0

Goméz JF, Nieves MH, Gayubo SF, Nieves-Aldrey JL (2017) Terminal-instar larval systematics and biology of west European species of Ormyridae associated with insect galls (Hymenoptera, Chalcidoidea). ZooKeys 644:51-88. https://doi.org/10.3897/zookeys.644.10035

Guyot V, Castagneyrol B, Vialatte A et al (2015) Tree diversity limits the impact of an invasive forest pest. PLoS ONE 10:e0136469. https://doi.org/10.1371/journal.pone.01364 69

Hambäck PA, Beckerman AP (2003) Herbivory and plant resource competition: a review of two interacting interactions. Oikos 101:26-37. https://doi.org/10.1034/j.16000706.2003.12568.x

Hambäck PA, Inouye BD, Andersson P, Underwood N (2014) Effects of plant neighborhoods on plant-herbivore interactions: resource dilution and associational effects. Ecology $95: 1370-1383$

Hatcher PE, Paul ND, Ayres PG, Whittaker JB (1994) The effect of a foliar disease (rust) on the development of Gastrophysa viridula (Coleoptera: Chrysomelidae). Ecol Entomol 19:349-360. https://doi.org/10.1111/j.1365-2311.1994.tb0 0252.x

Jactel H, Brockerhoff EG (2007) Tree diversity reduces herbivory by forest insects. Ecol Lett 10:835-848. https://doi. org/10.1111/j.1461-0248.2007.01073.x

Jactel H, Menassieu P, Vetillard F et al (2006) Tree species diversity reduces the invasibility of maritime pine stands by the bast scale, Matsucoccus feytaudi (Homoptera: Margarodidae). Can J For Res 36:314-323

Jactel H, Birgersson G, Andersson S, Schlyter F (2011) Nonhost volatiles mediate associational resistance to the pine processionary moth. Oecologia 166:703-711. https://doi. org/10.1007/s00442-011-1918-z
Jactel H, Bauhus J, Boberg J et al (2017) Tree Diversity Drives Forest Stand Resistance to Natural Disturbances. Curr For Rep 3:223-243

Jones TS, Bilton AR, Mak L et al (2015) Host switching in a generalist parasitoid: contrasting transient and transgenerational costs associated with novel and original host species. Ecol Evol 5(2):459-465

Jost L (2006) Entropy and diversity. Oikos 113(2):363-375

Kaartinen R, Stone GN, Hearn J et al (2010) Revealing secret liaisons: DNA barcoding changes our understanding of food webs. Ecol Entomol 35:623-638. https://doi.org/10. 1111/j.1365-2311.2010.01224.x

Kambach S, Kühn I, Castagneyrol B, Bruelheide H (2016) The impact of tree diversity on different aspects of insect herbivory along a global temperature gradient-a meta-analysis. PLoS ONE 11:e0165815

Keane RM, Crawley MJ (2002) Exotic plant invasions and the enemy release hypothesis. Trends Ecol Evol 17:164-170. https://doi.org/10.1016/S0169-5347(02)02499-0

Kennedy TA, Naeem S, Howe KM et al (2002) Biodiversity as a barrier to ecological invasion. Nature 417:636-638. https:// doi.org/10.1038/nature00776

Knoll V, Ellenbroek T, Romeis J et al (2017) Seasonal and regional presence of hymenopteran parasitoids of Drosophila in Switzerland and their ability to parasitize the invasive Drosophila suzukii. Sci Rep 7:40697

Lazzarotto A (1993) Elementi di geologia e geomorfologia. In: Giusti F (ed) La storia naturale della Toscana meridionale. Silvana Editoriale, Siena, pp 19-87

Leles B, Xiao X, Pasion BO et al (2017) Does plant diversity increase top-down control of herbivorous insects in tropical forest? Oikos 000:001-008. https://doi.org/10.1111/oik. 03562

Letourneau DK, Jedlicka JA, Bothwell SG, Moreno CR (2009) Effects of natural enemy biodiversity on the suppression of arthropod herbivores in terrestrial ecosystems. Annu Rev Ecol Evol Syst 40:573-592. https://doi.org/10.1146/ annurev.ecolsys.110308.120320

Levine JM, Adler PB, Yelenik SG (2004) A meta-analysis of biotic resistance to exotic plant invasions. Ecol Lett 7:975-989. https://doi.org/10.1111/j.1461-0248.2004. 00657.x

Li Y, Ke Z, Wang S et al (2011) An exotic species is the favorite prey of a native enemy. PLoS ONE 6:e24299

Lotfalizadeh H, Askew RR, Fuentes-Utrilla P, Tavakoli M (2012) The species of Ormyrus Westwood (Hymenoptera: Ormyridae) in Iran with description of an unusual new species. Zootaxa 3300:34-44

Maltoni A, Mariotti B, Tani A (2012) Case study of a new method for the classification and analysis of Dryocosmus kuriphilus Yasumatsu damage to young chestnut sprouts. IFor Biogeosci For 5:50-59. https://doi.org/10.3832/ ifor0598-008

Matošević D, Quacchia A, Kriston É, Melika G (2014) Biological control of the invasive Dryocosmus kuriphilus (Hymenoptera: Cynipidae) — an overview and the first trials in Croatia. South-East Eur For. https://doi.org/10. 15177/seefor.14-05

McManus PS, Ewers FW (1990) The effect of Cryphonectria parasitica on water relations of American chestnut. Physiol Mol Plant Pathol 36:461-470 
Meijer K, Schilthuizen M, Beukeboom L, Smit C (2016) A review and meta-analysis of the enemy release hypothesis in plant-herbivorous insect systems. Peerj 4:e2778. https:// doi.org/10.7717/peerj.2778

Meyer JB, Gallien L, Prospero S (2015) Interaction between two invasive organisms on the European chestnut: does the chestnut blight fungus benefit from the presence of the gall wasp? FEMS Microbiol Ecol 91:fiv122. https://doi.org/10. 1093/femsec/fiv122

Moriya S, Shiga M, Adachi I (2003) Classical biological control of the chestnut gall wasp in Japan. In: Proceedings of the 1st international symposium on biological control of arthropods. USDA Forest Service, Washington, pp 407-415

Nakagawa S, Schielzeth H (2013) A general and simple method for obtaining $R^{2}$ from generalized linear mixed-effects models. Methods Ecol Evol 4:133-142. https://doi.org/10. 1111/j.2041-210x.2012.00261.x

Nunez-Mir GC, Liebhold AM, Guo Q et al (2017) Biotic resistance to exotic invasions: its role in forest ecosystems, confounding artifacts, and future directions. Biol Invasions. https://doi.org/10.1007/s10530-017-1413-5

Oksanen J, Blanchet G, Friendly M, et al (2017) Vegan: community ecology package. R package version 2.4-2. https:// CRAN.R-project.org/package=vegan. Accessed 20 Mar 2017

Palmeri V, Cascone P, Campolo O et al (2014) Hymenoptera wasps associated with the Asian gall wasp of chestnut (Dryocosmus kuriphilus) in Calabria, Italy. Phytoparasitica 42:699-702. https://doi.org/10.1007/s12600-014-0411-8

Panzavolta T, Bernardo U, Bracalini M et al (2013) Native parasitoids associated with Dryocosmus kuriphilus in Tuscany, Italy. Bull Insectol 66:195-201

Quacchia A, Moriya S, Bosio G et al (2008) Rearing, release and settlement prospect in Italy of Torymus sinensis, the biological control agent of the chestnut gall wasp Dryocosmus kuriphilus. Biocontrol 53:829-839. https://doi.org/10. 1007/s10526-007-9139-4

Quacchia A, Moriya S, Askew R, Schönrogge K (2014a) Torymus sinensis: biology, host range and Hybridization. Acta Hortic. https://doi.org/10.17660/ActaHortic.2014. 1043.13

Quacchia A, Moriya S, Bosio G (2014b) Effectiveness of Torymus sinensis in the biological control of Dryocosmus kurophilus in Italy. Acta Hort 1043:199-204

R Core Team (2015) R: a language and environment for statistical computing. R Foundation for Statistical Computing, Vienna, Austria

Randlkofer B, Obermaier E, Hilker M, Meiners T (2010) Vegetation complexity-The influence of plant species diversity and plant structures on plant chemical complexity and arthropods. Basic Appl Ecol 11:383-395

Rigling D, Prospero S (2017) Cryphonectria parasitica, the causal agent of chestnut blight: invasion history, population biology and disease control. Mol Plant Pathol. https:// doi.org/10.1111/mpp. 12542

Rigot T, van Halder I, Jactel H (2014) Landscape diversity slows the spread of an invasive forest pest species. Ecography 37:648-658. https://doi.org/10.1111/j.1600-0587.2013.00 447.x
Riihimäki J, Kaitaniemi P, Koricheva J, Vehviläinen H (2005) Testing the enemies hypothesis in forest stands: the important role of tree species composition. Oecologia 142:90-97. https://doi.org/10.1007/s00442-004-1696-y

Rizvi SZM, Raman A, Wheatley W et al (2015) Influence of Botrytis cinerea (Helotiales: Sclerotiniaceae) infected leaves of Vitis vinifera (Vitales: Vitaceae) on the preference of Epiphyas postvittana (Lepidoptera: Tortricidae): Effect of B. cinerea infection on E. postvittana. Austral Entomol 54:60-70. https://doi.org/10.1111/aen.12093

Root RB (1973) Organization of a plant-arthropod association in simple and diverse habitats: the fauna of collards (Brassica oleracea). Ecol Monogr 43:95-124

Schielzeth H, Nakagawa S (2013) Nested by design: model fitting and interpretation in a mixed model era. Methods Ecol Evol 4:14-24. https://doi.org/10.1111/j.2041-210x. 2012.00251.x

Schuldt A, Both S, Bruelheide H et al (2011) Predator diversity and abundance provide little support for the enemies hypothesis in forests of high tree diversity. PLoS ONE 6:e22905. https://doi.org/10.1371/journal.pone.0022905

Schuldt A, Bruelheide H, Härdtle W et al (2015) Early positive effects of tree species richness on herbivory in a large-scale forest biodiversity experiment influence tree growth. J Ecol 103:563-571. https://doi.org/10.1111/1365-2745.12396

Schuldt A, Hönig L, Li Y et al (2017) Herbivore and pathogen effects on tree growth are additive, but mediated by tree diversity and plant traits. Ecol Evol 7(18):7462-7474

Shea K, Chesson P (2002) Community ecology theory as a framework for biological invasions. Trends Ecol Evol 17:170-176. https://doi.org/10.1016/S0169-5347(02)024 95-3

Sih A, Bolnick DI, Luttbeg B et al (2010) Predator-prey naïveté, antipredator behavior, and the ecology of predator invasions. Oikos 119:610-621. https://doi.org/10.1111/j.16000706.2009.18039.x

Simberloff D (2006) Invasional meltdown 6 years later: important phenomenon, unfortunate metaphor, or both? Ecol Lett 9(8):912-919

Simberloff D, Von Holle B (1999) Positive interactions of nonindigenous species: invasional meltdown? Biol Invasions 1(1):21-32

Stone GN, Schönrogge K, Atkinson RJ et al (2002) The population biology of oak gall wasps (Hymenoptera: Cynipidae). Annu Rev Entomol 47:633-668

Strauss SY, Cacho NI, Schwartz MW et al (2015) Apparency revisited. Entomol Exp Appl 157:74-85. https://doi.org/10. 1111/eea. 12347

Tack AJM, Dicke M (2013) Plant pathogens structure arthropod communities across multiple spatial and temporal scales. Funct Ecol 27:633-645. https://doi.org/10.1111/13652435.12087

Tack AJM, Gripenberg S, Roslin T (2012) Cross-kingdom interactions matter: fungal-mediated interactions structure an insect community on oak: fungus-plant-insect interactions. Ecol Lett 15:177-185. https://doi.org/10.1111/j. 1461-0248.2011.01724.X

Tahvanainen JO, Root RB (1972) The influence of vegetational diversity on the population ecology of a specialized herbivore, Phyllotreta cruciferae (Coleoptera: Chrysomelidae). 
Oecologia 10:321-346. https://doi.org/10.1007/BF0 0345736

Tosi L, Beccari G, Rondoni G et al (2015) Natural occurrence of Fusarium proliferatum on chestnut in Italy and its potential entomopathogenicity against the Asian chestnut gall wasp Dryocosmus kuriphilus. J Pest Sci 88:369-381. https://doi. org/10.1007/s10340-014-0624-0

Vannini A, Vettraino A, Martignoni D et al (2017) Does Gnomoniopsis castanea contribute to the natural biological control of chestnut gall wasp? Fungal Biol 121:44-52. https://doi.org/10.1016/j.funbio.2016.08.013

V.V.A. A. (2008) Soil Atlas of Europe. http://eusoils.jrc.ec. europa.eu/projects/Soil_Atlas/Index.html

White JA, Whitham TG (2000) Associational susceptibility of cottonwood to a box elder herbivore. Ecology 81: $1795-1803$

Wilby A, Thomas MB (2002) Are the ecological concepts of assembly and function of biodiversity useful frameworks for understanding natural pest control? Agric For Entomol
4:237-243. https://doi.org/10.1046/j.1461-9563.2002.001 $65 . \mathrm{x}$

Wilcox RC, Fletcher RJ (2016) Experimental test of preferences for an invasive prey by an endangered predator: implications for conservation. PLoS ONE 11:e0165427. https:// doi.org/10.1371/journal.pone.0165427

Wilsey BJ, Polley HW (2002) Reductions in grassland species evenness increase dicot seedling invasion and spittle bug infestation. Ecol Lett 5:676-684. https://doi.org/10.1046/j. 1461-0248.2002.00372.x

Zhang QH, Schlyter F (2004) Olfactory recognition and behavioural avoidance of angiosperm nonhost volatiles by conifer-inhabiting bark beetles. Agric For Entomol 6:1-19. https://doi.org/10.1111/j.1461-9555.2004.00202.x

Zhang Z-Y, Tarcali G, Radocz L et al (2009) Chestnut gall wasp, Dryocosmus kuriphilus Yasumatsu in China and in Hungary. J Agric Sci 38:123-128

Zuur AF, Ieno EN, Walker N et al (2009) Mixed effects models and extensions in ecology with R. Springer, New York 